\title{
Turn taking and power relations in Plautus' Casina
}

\author{
Łukasz Berger
}

(Adam Mickiewicz University in Poznań)

\begin{abstract}
The paper interprets the verbal behaviour of pater familias and his subordinates in Plautus' Casina through the lenses of conversation analysis and im/politeness research. According to the approach here presented, turn-allocating techniques can function as a means of depicting power relationships - whether presupposed or emergent and negotiated on-stage - among high- and low-status characters in Roman comedies. The analysed data draw a connection between the active initiating of the dialogue, the management of the turn space, and speakership rights (e.g. silencing through the directive tace) with the dominant social position, prototypically of high-born men. The authority of Roman slave-owners, reproduced in the characterisation of the senex, has been viewed in relation to potestas, the Roman conceptualisation of default social dominance. On the other hand, the subordinate role of slaves arguably is governed by quasi-mandatory patterns of linguistic use interpreted as politic behaviour which - in interaction with free-born citizens - consisted of obedience, withdrawal, lack of initiative, and deprivation of face.
\end{abstract}

\section{Keywords}

Plautus; Casina; turn taking; im/politeness; power; pater familias; silence; greeting

The paper is part of the international research project "Conversation in Antiquity. Analysis of Verbal Interaction in Ancient Greek and Latin" (SI1/PII/2019-00283), financed by the Community of Madrid. I want to express my gratitude to the anonymous reviewers for their insightful suggestions and corrections. 


\section{Introduction}

In the present paper, I aim to offer an analysis of the language of domination and (male) authority in the Plautine comedy Casina. Due to limitations of space, the main focus will be on turn management as an instrument of exerting power during the verbal interactions of the pater familias with the members of his household.

The central premise here is that the dialogic exchange inside the comedy functions as a simulation - whether naturalistic or artificial and poetic - of spoken communication. In recent years, the scholars interested in interpersonal relations represented inside Roman comedy have recurred to various frameworks provided by the $\mathrm{Im} /$ politeness Research. Less frequently, however, these investigations include aspects of the organization of talk-in-interaction, as described by Conversation Analysis (CA). ${ }^{1}$ The approach adopted in the following pages, therefore, seeks to combine insights from both methodologies in order to shed some light on how the authoritarian characters exert power and gain control through talk. To this end, I will use excerpts from one selected play, supplied - whenever necessary - with evidence from other works by Plautus (or Terence).

Casina is considered one of the latest and the most accomplished plays of the Sarsinate author. The comedy tells a story of an old citizen Lysidamus, who - competing with his son - falls in love with a handmaid called Casina. In Plautus' reworking of the Greek original, a typical father-son conflict (cf. Mercator) is substituted by the struggles between Lysidamus and his domineering wife Cleostrata, who acts on behalf of the boy. ${ }^{2}$ The freeborn matrona plots against her husband through the agency of her slaves, including the son's former armour-bearer (armiger) Chalinus. On the other hand, as stressed by McCarthy (2000: p. 83), Cleostrata's tricks take as a starting point her apparent obedience to her husband's wishes. Lysidamus is also forced to use the help of his servant Olympio, the uilicus who - after winning the slave bride in a lot-drawing scene - is gradually taking control over his master. Thus, all members of the household interact with the pater familias in a manner that either asserts or subverts the social hierarchy and his position of power.

As a result, according to Rei (2005), Casina raises important questions about the male authority and the distinction between the free and unfree members of a household. Some time ago, McCarthy (2000: ch. 3) offered a very complex and insightful analysis of the art of authority in Casina, viewed from a dramaturgical perspective. The purpose of this paper is to supply the existing accounts of both Lysidamus' power and the opposition to it with some pragmatically informed understanding of the on-stage communication.

1 CA was developed in the late 1960s and early 1970s as a methodology of studying social interaction with a particular focus on everyday conversation. See Levinson (1983: pp. 284-370) and Schegloff (2007) for a comprehensive introduction.

2 Most of the scholarship on Casina concerns the originality of Plautus' invention and his (possible) additions - see O'Bryhim (1989), Konstan (2014), and an overview of earlier studies in Cody (1976: pp. 461-472). More recently, Barbiero (2020) has revisited the rhetoric of novelty throughout the play. 


\section{Im/politeness and power in Roman comedy}

Still central for the Im/politeness Research is the theoretical apparatus introduced by Brown \& Levinson (1987: p. 62), who relate the phenomenon with the concept of 'face' defined as the "basic wants, which every member knows every other member desires, and which in general it is in the interests of every member to partially satisfy". ${ }^{3}$ According to the authors (Brown \& Levinson 1987: p. 70), these face-wants can be divided into the need to be appreciated, included and valued (positive-face wants) and, on the other hand, the need for one's actions to be unimpeded (negative-face wants). From this perspective, politeness comes down to the strategies of message formulation, which are launched in order to avoid or compensate a potential threat to both aspects of the face. In most recent studies, however, the methodological orientation of the $\mathrm{Im} /$ politeness Research has changed significantly from universal (scholars') generalizations on the phenomenon towards culture-specific and local (participants') evaluations of im/ polite behaviour. Moreover, the focus on single (face-threatening) speech acts has been substituted by analysing whole stretches of talk. ${ }^{4}$ Therefore, part of the so-called discursive approaches to im/politeness recur to CA (e.g. Mills 2003, Piirainen-Marsh 2005) and especially to its basic methodological premise that the current utterance shows the speaker's understanding of the previous action, including its im/polite value.

One cannot overlook, however, that these methodological tools were designed (originally) for the contemporary egalitarian societies and, hence, might not accurately account for the im/politeness in the highly hierarchical Roman Republic which included acute social inequalities, slavery, and other forms of socio-economic dependency. ${ }^{5} \mathrm{Mc}-$ Carthy (2000: p. 18) stresses that the Plautine theatre represented and was created for "a culture that never shrank from explicitly ranking people and assigning unequal rights and responsibilities". Therefore, instead of seeking to confirm the universal nature of the phenomenon, scholars start with the localised (emic) conceptualization of Roman face and im/politeness itself. As argued by Hall (2005; 2009: p. 12), for instance, the concern for social status and excellence (dignitas), would constitute an essential part of the upper-class individual face.

According to Unceta's (2019) recent analysis of the available testimonies, the Latin-speaking authoritarian, patriarchal, and slaveholding society revolved around such culture-specific concepts as uerecundia, urbanitas or comitas (cf. Barrios-Lech 2016: pp. 35-39). The first one on the list, uerecundia, is glossed by Kaster (2005: p. 26) as "the self-restraint of the inferior parties, the respect they feel for their superiors, the virtue of

3 The first publication of the main part of the book took place in 1978. The concept of 'face' in their theory is derived from Goffman (1955).

4 See Culpeper (2011) for a summary of the criticism of Brown \& Levinson (1987) and for a comprehensive overview of the more recent theoretical proposals. The discursive approaches to im/politeness are discussed in Haugh (2007) and Mills (2011).

5 E.g. Dickey (2016) evaluates the usefulness of the modern im/politeness theories on Latin directive speech acts. Most of the im/politeness-related phenomena in Roman comedy are addressed by Barrios-Lech (2016). Unceta (2018) gives an updated overview of other investigations in Latin scholarship. 
knowing their place and keeping to it". Thus, within a household, this feeling is proper to wives and children-thought to have less self-control than adult males-and never to slaves (Kaster 2005: p. 24). As explained by the scholar, uerecundia is based on a choice and implies voluntarily restraining one's action for the benefit of the addressee(s). The slaves, in turn, "have no autonomous volition, hence no actual self, hence no face to maintain or lose" (Kaster 2005: p. 23; cf. Stewart 2012: p. 8).

From this it follows that in default master-slave relations, there is no space for politeness transactions. Unceta (2019: p. 304) argues that the subordinates, during interactions with their superiors, are expected to show maximal deference by emphasizing distance and separateness. Instead of acting strategically, they follow the rules of decorum, the Roman conceptualisation of Watts' (2003: p. 19) politic behaviour, namely the language use that "is perceived to be appropriate to the social constraints of the ongoing interaction." Any violation of decorum would be a salient verbal behaviour, likely to be reported by the superior, and negatively evaluated as impoliteness, as well as an act of challenging the authority.

As for the Roman concepts of power, there is a prominent distinction between the less binding auctoritas, that derives from the (elite members') personal qualities anchored in dignitas, and the institutionalised idea of potestas, which is attached to offices and social roles. ${ }^{7}$ Thus the latter type of coercive power (potestas) rested on absolute obedience and appears in Plautus in the context of the dominant role of the pater familias. ${ }^{8}$ Since the Roman slaveholders did not need any concern for the face of their slaves, Ridealgh \& Unceta (forthcoming) describe potestas in terms of non-politeness: most of the masters' expressive forms could be interpreted as face-threatening acts and yet, given the hierarchical imbalance, their verbal behaviour does not impact on the relationship with the low-power addressee(s). ${ }^{9}$ Accordingly, when describing the powerful linguistic styles of superiors in Roman comedy, the scholars concentrate on directive speech acts or tokens of verbal abuse (insults, threats).

In Casina, quite significantly, the pattern for the language of potestas can be best illustrated by the verbal behaviour of the mistress of the house, Cleostrata. In her first appearance on stage (1), she gives series of unmitigated instructions to her servants before heading for the neighbour's house. The slave girl Pardalisca informs her at the threshold that her husband expects his lunch to be prepared and, thus, indirectly suggesting that Cleostrata should change her dispositions. In reaction, the matrona orders the maid to be quiet and sends her away.

6 In Roman comedy, the slave's servile attitude and respect for the master's dominance is expressed by the slaves themselves (e.g. Plaut., Aul. 587-590).

7 See further Casinos Mora (1999) and Gotter (2008: pp. 200-203).

8 The term potestas is used - in a strict meaning - to designate the power of a master over his slaves (Plaut., Cas. 282; Capt. 926) a husband over his wife (Aul. 534), and a father over his children (Persa 341-344; Poen. 1276; Stich. 53, 69).

9 It is worth noting that Ridealgh \& Unceta (forthcoming) propose to use the Roman idea of potestas as a cross-cultural, theoretical concept (Potestas). I am grateful to the authors for sharing the final draft of their paper before the publication. 
CLEO. Opsignate cellas, referte anulum ad me: / ego huc transeo in proxumum ad meam uicinam. / uir siquid uolet me, facite hinc accersatis. /

PAR. Prandium iusserat senex sibi parari. /

CLEO. St! / tace atque abi: neque paro neque hodie coquetur [...] (Plaut., Cas. 144-150).

['CLEO. Seal the pantries and return the ring to me. I'm going next door here to my neighbour. If my husband wants anything from me, do fetch me from here. PAR. The old master had ordered that lunch should be prepared for him. CLEO. Hush! Be quiet and be off. I'm not preparing any and it won't be cooked today.' $]^{10}$

In his thorough examination of the speech patterns in Roman comedy, Barrios-Lech (2016: pp. 222-223) demonstrates that the speech of the masters is full of unmediated expressions and peremptory directives, while the slaves in general employ more indirectness and various strategies of withdrawal. Thus Pardalisca's use of an indirect speech act, which leaves the interpretation of the utterance to her mistress, is also fitting her subordinate social role.

The comedy authors can stage the role reversal in a master-slave relation via modifications of these speech patterns using politeness strategies. In the following excerpt (2), Lysidamus, the master of the house, seems to be addressing the negative-face wants of his most trusted slave by mitigating the directive act with parumper ('for a little while'), which minimizes the (implied) imposition of the action.

\section{LYS. St! tace parumper. \\ OL. Quid uis?}

LYS. Eccum exit foras / Chalinus intus cum sitella et sortibus (Plaut., Cas. 350-351).

['LYS. Hush! Be quiet for a bit. OL. What do you want? LYS. Look, Chalinus is coming out with the urn and the lots.']

Accordingly, the unfree subordinate is treated as an interlocutor of a similar status, equipped with an actual face to maintain and with volition, confirmed also by his noncompliant reaction. ${ }^{11}$ As a consequence, by comparing the act-formulation strategies among the slaves and the high-power characters, one can trace Plautus' distortions in reproducing the language of authority in Casina. This paper, however, seeks to supply

10 The Plautus' text and its English translation follow the edition by De Melo (2011-2013).

11 See also tace parumper uttered by the free-born Menaechmus to his slave (Plaut., Men. 348). There the role reversal is confirmed - in addition - by the face-giving action of accepting and praising the subordinate's advice (346-347). Elsewhere, the directive softened with parumper appears in face-sensitive dialogues of free-born characters: two old citizens (Aul. 199), two young male friends (Merc. 922), or a young boy asking a senex for permission to speak (Most. 1152). On occasions, the mitigating device is used by low-status characters when talking to their superiors (Cist. 712: LAMP. [...] tace>amus, era, parumper. 'LAMP. [...] Let's be quiet for a bit, my mistress.'; cf. Curc. 357; Mil. 596). One should remember, however, that the basic meaning of parumper might not always have politeness-related side effects (e.g. Ter., Andr. 714; Plaut., Truc. 326. Bacch. 794). In a similar context, see Risselada's (1994) discussion on representational and illocutionary particles. 
the aforementioned resources with some conversational devices that operate on the level of interaction and turn management.

\section{Turn management}

The description of the machinery behind turn taking, outlined in the seminal paper by Sacks \& Schegloff \& Jefferson (1974), is central for the methodology of CA. ${ }^{12}$ According to the authors, the constant flow of conversation is governed by the rule that (overwhelmingly) only one party speaks at a time. This orderliness needs some coordination and collaboration from the participants, who must predict when the current speaker is about to release the floor, allowing the other party to intervene with no risk of interrupting. Moreover, any blatant violation of the turn-taking system can be analysed as face-threatening acts (Brown \& Levinson 1987: pp. 232-233). ${ }^{13}$ Thus in the amicable conversation between two free-born senes (3), the utterances project boundaries that are easy to perceive. They form syntactically complete sentences, which - in addition - correspond prototypically to prosodic and pragmatic units: the directive act launched by Lysidamus is followed by Alcesimus' expression of compliance.

LYS. Fac uacent aedes.

ALC. Quin edepol seruos ancillas domo / certum est omnis mittere ad te (Plaut., Cas. 521522).

['LYS. Make sure your house is empty. ALC. Yes, yes; I have decided to send all slaves and slave girls away from my home over to yours.']

Note that Alcesimus' negative-face of an autonomous agent is partially mitigated by his impersonal formulation of compliance with certum est ('it is resolved' in place of 'I have decided'). Unlike slaves, free-born characters should not be too eager to fulfill directive acts launched by their peers. ${ }^{14}$

Furthermore - in terms of CA - two turns by different speakers (in (3): request and granting) constitute an adjacency pair, where the first turn by one interlocutor (first pair part) sets up an expectancy for a particular reaction (the second pair part) of another. Accordingly, the absence of the second element becomes noticeable and marked (Schegloff 2007: pp. 13-27). It is crucial, nonetheless, to remember that for conversation analysts every spate of talk should be seen as delivering an action rather than expressing

12 See a critical overview in O'Connell \& Kowal \& Kaltenbacher (1990). Herman (1995: pp. 76-163) and Herman (2002) are a good introduction to the turn-taking systematics for readers of drama. For the CA-informed methodology in describing the structure of dialogues in Roman comedy, see Müller (1997) and Berger (2019).

13 It must be noted that a connection between talk organization and face-threat or face-work has proven to be problematic for the 'purist' methodological school of CA (see Geyer 2008: pp. 35-37, with further references).

14 See the commentary by Donatus (ad Eun. 500): FIAT 'faciam' vel 'fiet' diceret servus, liber vero tamquam et ipse iubet sibi. (cf. ad Hec. 358). 
meaning (Levinson 2013). In an adjacency pair retrieved from (1), for instance, Pardalisca reacts to Cleostrata's order with silence and non-linguistic action rather than with verbal tokens of compliance (see (4) below).

\title{
CLEO. St! / tace atque abi.
}

PAR. [compliance] (Plaut., Cas. 149-150).

['CLEO. Hush! Be quiet and be off. PAR. (leaves the stage).']

When explaining techniques for allocating turns among the interlocutors, Sacks \& Schegloff \& Jefferson (1974: pp. 704-705) provide a set of rules which can be applied recursively and seem universal yet context-sensitive. According to the orderly design of talk, the current speaker, while reaching a possible completion point, can pass the turn to another or continue talking. Since the adjacency pair is the minimal unit of interaction, it also serves as the most common mechanism responsible for progression in the turn taking (Schegloff 2007: p. 4). Accordingly, the question-answer format in the following excerpt (5) facilitates the smooth transitions of speakership until Olympio hears somebody coming out from inside the house.

\author{
LYS. Quo argumento? \\ OL. Nimis tenax es. \\ LYS. Num me expertu's uspiam? / \\ OL. Di melius faciant. sed crepuit ostium, exitur foras. / \\ LYS. Di hercle me cupiunt seruatum. (Plaut., Cas. 812-814)
}

['LYS. How so? OL. You're very persistent. LYS. You haven't tried me out anywhere, have you? OL. May the gods forbid! But the door has creaked, they're coming out. LYS. The gods want me saved.']

Then he decides to hold on to the floor by adding another turn component (introduced with the adversative sed) and, as a result, he ends up launching a multi-unit turn.

Finally, it seems worth stressing that CA is engaged with drawing a connection between the orderliness of the verbal interaction (the so-called micro-level) and the social organization (macro-level). ${ }^{15}$ Accordingly, the way the rules of speakership assignment operate, in a broader perspective, will systematically inform us who - in the reality of Roman comedy or a given play - is preferably selected as the next speaker or, on the contrary, who tends to be exempt from the speakership rights or even deprived thereof with impunity. In the next sections, the functioning of the turn-taking system will be analysed in the context of displaying hierarchical inequality within the relations of the pater familias and the members of his household.

15 Compare Schegloff (1987: p. 204) stating that turn-taking is the "apotheosis of social organization" since "it coordinates the behaviour of the participants - all participants - by allocating differentially at any moment differing opportunities for differing types of participation.” 


\section{Male authority and turn taking in Casina}

According to the conversational order represented in the Plautine comedies, the management of conversation belongs to the master of the house. Be the best illustration a scene from Amphitruo (6), where the pater familias intervenes in a quarrel between his wife and a slave. Amphitruo manages the interaction either through the act of silencing its participants (tace tu) or by yielding them the floor (dic tu). His powerful position is unchallenged as he dominates over both the high-status female and the unfree male members of the household.
ALC. Vae capiti tuo.
SOS. Tua istuc refert... si curaueris. /
ALC. Iterum iam hic in me inclementer dicit, atque id sine malo. /
AMPH. Tace tu. tu dic: egone aps te abii hinc hodie cum diluculo? /
ALC. Quis igitur nisi vos narravit mi illi ut fuerit proelium? (Plaut., Amph. 741-744)
['ALC. Bad luck to you! SOS. To you... this is important, if you see it. ALC. He's abus- ing me the second time already, and without punishment. AMPH. Be quiet, you. You tell me: I went away from here at dawn today, did I? ALC. Well, then who told me how the battle went there, if not you?']

As far as the conversational order is concerned, to quieten someone equals depriving them of speakership rights by excluding them from the on-going interaction and cancelling the sequential implications of their last turn. Towards free-born citizens, such a turn-taking violation threatens the positive-face wants of the addressee as a rightful participant of the conversation (cf. Brown \& Levinson 1987: p. 67). ${ }^{16}$ The act of silencing the slaves, however, is commonly depicted throughout Roman comedy as a means of censoring their speech, controlling their behaviour on-stage and - more importantly - excluding the servants from the on-going interaction. ${ }^{17}$ One of the previous excerpts (see 1) from Casina has already provided an example of an authoritarian style enacted by the matrona, who was forcing the subordinates to be silent. In the following multi-party conversation, the master of the house silences Olympio and Chalinus in order to stop their verbal sparring, which takes the form of confrontational side dialogues, like the one given in (7).
OL. Te uno adest plus quam ego uolo./
CHAL. Tibi quidem edepol ita uidetur: stimulus ego nunc sum tibi: / fodico corculum: assudas- cis iam ex metu, mastigia. /
LYS. Tace, Chaline.

16 E.g. the slave girl asking a free-born youth to be quiet with a mitigating strategy in Ter., Eun. 685 (tace obsecro) with the corresponding commentary by Donatus. Cf. Plaut., Cas. 195a-196, 204/5.

17 The slaves are expected to keep their mouth in check and be silent (e.g., Plaut., Epid. 261; Mil. 477, 564; Ter., Eun. 721-722; Haut. 748). Even the clever slaves get hushed by their young masters despite their friendly relations (see e.g., Plaut., Pseud. 209-211), sometimes even despite being quiet (Curc. 156). 
CHAL. Comprime istum. (Plaut., Cas. 359-363)

['OL. With you there is one more person present than I want. CHAL. To you it seems like that. I'm your cattle prod now; I'm stabbing your little heart. You're already sweating for fear, whip fodder. LYS. Be quiet, Chalinus. CHAL. Subdue this one.']

Lysidamus' attempts to discipline both servants are not very efficient. Unlike Sosia in (6), Chalinus (7) reacts defensively to his master's command by launching an alternative second pair part - defined by Schegloff (2007: pp. 16-17) as 'counter' - that reverses the direction of constraint. By contrast, the old master's ally Olympio (8) assumes here somewhat ambiguous servile attitude, given that he is consequently depicted as dominant and self-confident (Anderson 1983: pp. 16-17). ${ }^{18}$ When silenced by Lysidamus, the slave overtly complies with the directive act (taceo 'I'm quiet') and yet holds the turn by starting to pray out loud. Thus, paradoxically he manages to give a preferred second pair part, while infringing the rules of politic behaviour through camouflaged disobedience.

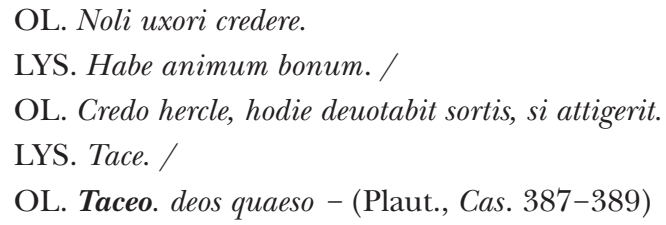

['OL. Don't trust your wife. LYS. Take heart. OL. I believe she'll bewitch the lots if she touches them. LYS. Be quiet. OL. Yes, I'm quiet. I pray to the gods -']

A few turns further, Lysidamus disciplines both servants once again (9), but only the uilicus takes the turn in order to close the adjacency pair with linguistic tokens of compliance (taceo). Accordingly, he presents himself as responsive and obedient, while he still signals his participation in the on-going interaction. ${ }^{19}$

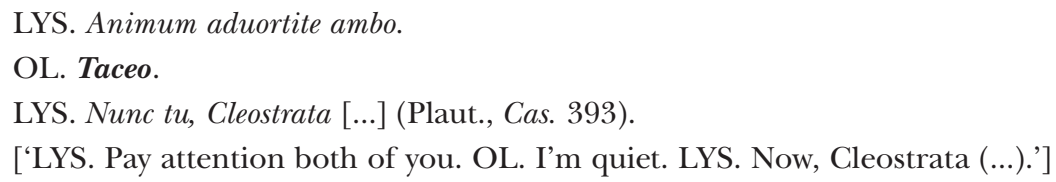

This type of sequencing seems to be salient also in the scenes of closing up the whole interaction with servants in order to send them off the stage. The last line of Staphyla (10) from Aulularia, before she returns inside the house, mockingly echoes her master's dispositions (compare with (4) above).

18 However, as pointed out by Moore (1998: p. 168), from the perspective of the performance, Olympio would be lower in the hierarchy of rapport, given that he often gets overheard (e.g. by Chalinus) and almost never speaks directly to the audience.

19 Zebrino (2013: pp. 127-128) discusses all the performative uses of taceo, which she associates with the slaves' loquacity and their complacent attitudes. In master-slave interactions, however, most instances belong to strong-personality servants - Lampadio (Plaut., Cist. 751), Palinurus (Curc. 131a), Milphio (Poen. 295) - and appear in non-cooperative contexts. 
(10) EVC. Tace atque abi intro.

STAPH. Taceo atque abeo. (Plaut., Aul. 103)

['EUC. Be quiet and go inside. STA. Yes, I am quiet and I am going.']

Arguably, these expansive uses of turn space which could be realized simply as silent action exceed the politic behaviour and hence contribute to gain additional pragmatic values. In a way, these cases can be considered as nuanced examples of a face-saving or in the case of Roman slaves - a face-restoring action, given that they imply the speaker's individual self and volition (see Section 2). The slave's cheeky use of verbalized silence as an act of rebellion against decorum is confirmed by the scene from Pseudolus (11).

CALI. Vah! tace.

PSEV. Quid est? /

CALI. Male morigeru's [male facis] mi quom sermoni huius opsonas. / PSEV. Taceo.

CALI. At taceas malo multo quam tacere dicas (Plaut., Pseud. 206/207-209)

['CALI. Bah! Be quiet. PSEU. What's the matter? CALI. You obey me badly by drowning out his speech. PSEU. I'm quiet. CALI. But I'd much prefer you to be quiet rather than just say that you're quiet.']

Here, the young master states expressly that he prefers an actual quiet and obedient servant than one who breaks the silence with the interactionally charged taceo.${ }^{20}$ Returning to the power relations in Casina, Olympio - with much more confidence - refuses to be silenced by Lysidamus by the end of the play (826: LYS. Tace. OL. Non taceo. 'LYS. Be quiet. OL. No, I won't.') and in a very emphatic way in the climax scene (992: LYS. Non taces? OL. Non hercle uero taceo. 'LYS. Won't you be quiet? OL. No, [hercle uero] I won't'). Accordingly, Zebrino (2013: p. 141) duly concludes that this progression marks an evolution of the relation between Lysidamus and Olympio: from complacent to openly hostile. I would argue, however, that the cheeky use of taceo in the reaction to Lysidamus' orders already contains elements of challenging the master's potestas.

The general rules of politic behaviour, as implied by the testimonies within the comedy corpus, dictate that the servants in an interaction with upper-class citizens should be non-active and submissive. Accordingly, a slave is disciplined and rebuked, when impolitely interrupting their old master ${ }^{21}$ or self-selecting as the next speaker in his presence. ${ }^{22}$ Neither are the servants addressed by free-born characters as legitimate interlocutors in a multi-party conversation. ${ }^{23}$ The subordinate role in the turn-taking system is especially relevant during conversational tasks which require the speaker's initiative and entail a high level of imposition, such as opening a dialogue. Therefore, when initiat-

20 Cf. Plaut., Poen. 261-262 (with a similar metapragmatic comment by a young master) and Bacch. 990-990a.

21 Plaut., Rud. 1389-1392.

22 E.g., Plaut., Amph. 802-803; Cist. 750-755; Epid. 251; Men. 626-627; Rud. 118-119.

23 Plaut., Men. 182; Poen. 330-332. On master-slave greeting scenes, see Barrios-Lech (2016: pp. 224-227) and Cabrillana (2019: pp. 22-23). 
ing the interaction, submissive slaves are supposed to start a conversation by presenting themselves in front of their superiors and by signalling their availability for engaging into contact. ${ }^{24}$ The slave Chalinus, however, is described by Lysidamus as worthless and unreliable, especially compared to his own protégé, Olympio. ${ }^{25}$ Hence, after the armiger emerges for the first time from the house, on the old master's explicit demand, the latter reacts with a hateful curse.

\section{LYS. Qui illum di omnes deaeque perdant! \\ CHAL. Te uxor aiebat tua... / me uocare. \\ LYS. Ego enim uocari iussi.}

CHAL. Eloquere quid uelis. /

LYS. Primum ego te porrectiore fronte uolo mecum loqui: / stultitia est ei te esse tristem quoius potestas plus potest (Plaut., Cas. 279-282).

['LYS. May all the gods and goddesses! CHAL. No, you... were calling me, your wife said. LYS. Yes, I had you called. CHAL. Tell me what you want. LYS. First, I want you to speak to me in a more respectful way. It's stupidity to be sulky to someone who has greater authority.']

In his first line, Chalinus (12) seems to be playing out the part of an obedient slave by confirming his readiness to respond to Lysidamus' summons. ${ }^{26}$ Thus, the opening turn acquires a strictly phatic interpretation while fulfilling Laver's (1975: p. 220) initiatory function of helping the participants to get the conversation under way. ${ }^{27}$ Lysidamus, however, does not use the opportunity to insert the first topic slot (see Berger 2016) and, instead, prefers to recall his authority through emphasizing that he is the one who had him summoned (ego enim te uocari iussi). The slave is taking the initiative by launching another first pair part and issuing an unmitigated directive (eloquere quid velis), by which he demands the reason for the talk. For the old man, however, this bold manoeuvre, added apparently to the servant's grim attitude, ${ }^{28}$ must be deemed disrespectful and unacceptable. In a prescriptive and alliterative style, the master recalls his potestas over the slave (stultitia est ei te esse tristem quoius potestas plus potest).

From a CA-informed perspective, conversational openings, like the one presented in (12), cover the function of 'gatekeeping', that is of managing the rights and conditions of access to a given interaction (Schegloff 1986: p. 113). In a similar context, Goffman

24 See Plaut., Amph. 956; Most. 1075-1076. Slaves are asking for permission to address their master in Plaut., Rud. 1227-1229; Ter., Haut. 973-974.

25 Plaut., Cas. 254-258, 268.

26 However, Chalinus' strong interactional position is evident for the audience, given that he uses the end of the old man's monologue to give - via co-construction of turns - a double entendre to his opening line (Moore 1998: p. 172). See Plaut., Bacch. 999.

27 Phatic interpretation of utterances in Plautus' comedies are treated in Berger (2018).

28 MacCary \& Willcock (1976: p. 132, ad loc.) explain that "porrecta frons would be the opposite of contracta frons 'a frown'”. Accordingly, Lysidamus' comment seems to mostly concern his interlocutor's facial expression or bodily position. I argue, nonetheless, that it is also triggered by an im/polite evaluation of his turn-taking mechanism. 
(1971: p. 40) talks about a 'conversational preserve', namely "the right of an individual to exert some control over who can summon him into talk and when he can be summoned." Accordingly, Lysidamus' verbal dominance might be viewed in relation to his active role as the initiator of all the on-stage dialogues with the members of his household (see Table 1). He launches the first salutation pair part towards his wife (Plaut., Cas. 229229a, 577), greets his proxy Olympio $(317,724,801)$ or summons the rest of the servants (358: 631, 789). As for the expression of im/politeness in the conversational openings, Lysidamus mitigates the access to someone else's conversational preserve, only talking to his wife and his protégé. In both cases, he recurs to tokens of marked positive politeness of either feigned (towards Cleostrata) or comically inverted intimacy (towards Olympio).

\begin{tabular}{|c|c|c|c|}
\hline speaker & verses & opening turn / first pair part of salutation & addressee(s) \\
\hline \multirow{8}{*}{$\begin{array}{l}\text { Lysidamus } \\
\text { (senex) }\end{array}$} & $229-229 a$ & $\begin{array}{l}\text { Vxor mea meaque amoenitas, / quid tu agis? } \\
\text { 'My wife and my pleassure, how are you?' }\end{array}$ & \multirow{2}{*}{$\begin{array}{l}\text { Cleostrata } \\
\text { (matrona) }\end{array}$} \\
\hline & 577 & $\begin{array}{l}\text { Quid agis, mea festiuitas? } \\
\text { 'How are you, my joy?' }\end{array}$ & \\
\hline & 317 & $\begin{array}{l}\text { Quid istuc est? quicum litigas, Olympio? } \\
\text { 'What's that? Who are you arguing with, Olympio?' }\end{array}$ & \multirow{3}{*}{$\begin{array}{l}\text { Olympio } \\
\text { (seruus) }\end{array}$} \\
\hline & 724 & $\begin{array}{l}\text { Bone uir, salue. } \\
\text { 'Greetings, my good man.' }\end{array}$ & \\
\hline & 801 & $\begin{array}{l}\text { Quid agis, mea Salus? } \\
\text { 'How are you, my savior?' }\end{array}$ & \\
\hline & 358 & $\begin{array}{l}\text { Quid uos agitis?29 } \\
\text { 'What are you two doing?' }\end{array}$ & \multirow{3}{*}{ other servants } \\
\hline & 631 & $\begin{array}{l}\text { Pardalisca! } \\
\text { 'Pardalisca!' }\end{array}$ & \\
\hline & 789 & $\begin{array}{l}\text { Quid tu hic agis? } \\
\text { 'What are you doing here?' }\end{array}$ & \\
\hline
\end{tabular}

Table 1. Lysidamus' opening turns, when initiating dialogue with the members of his household.

Before Lysidamus' final humiliation, the only character that approaches him and (angrily) initiates the conversation is another senex, the neighbour Alcesimus (593, see Table 2). Thus the Roman master of the house is portrayed as the one who penetrates - by his own rules - the conversational preserve of his subordinates, including the wife's.

In this light, one should understand the interpersonal tensions in the first dialogue with the armiger analysed above (12), as well as the pragmatic and social significance of the last scene in the play. After his misdeeds are in the open, Lysidamus is violently summoned by Chalinus and, then, greeted by two matronae, Cleostrata and her neighbour Myrrhina (Table 2). Apart from the violation of the rules of access, the humiliation of pater familias, as noted by Berger (2020: forthcoming), derives also from the contextual misapplication of the greeting formulae. In the comedy corpus, the expression quid agis, here launched by a female neighbour, belongs to the familiar idiom and is used by intimates or members of the same household (see its literal and idiomatic variants in Table

29 Here Lysidamus addresses Chalinus standing on the stage with Cleostrata. 
1). The formal third-person salutation iubeo te saluere, in turn, is aimed at creating distance and signals Cloestrata's estrangement from her husband (Barrios-Lech 2016: p. 186).

\begin{tabular}{|c|c|c|c|}
\hline speaker & verses & opening turn / first pair part of salutation & addressee \\
\hline $\begin{array}{l}\text { Alcesismus } \\
(\text { senex })\end{array}$ & 593 & $\begin{array}{l}\text { Ad te hercle ibam commodum. } \\
\text { 'I was going to you this very moment.' }\end{array}$ & \multirow{4}{*}{$\begin{array}{l}\text { Lysidamus } \\
(\text { senex })\end{array}$} \\
\hline $\begin{array}{l}\text { Cleostrata } \\
\text { (matrona) }\end{array}$ & 969 & $\begin{array}{l}\text { Iubeo te saluere, amator } \\
\text { 'My greetings, lover' }\end{array}$ & \\
\hline $\begin{array}{l}\text { Myrrhina } \\
(\text { matrona })\end{array}$ & 974 & $\begin{array}{l}\text { Quid agis, dismarite? } \\
\text { 'How are you, bigamist?' }\end{array}$ & \\
\hline $\begin{array}{l}\text { Chalinus } \\
\text { (seruus) }\end{array}$ & $959 / 60$ & $\begin{array}{l}\text { Heus! sta illico, amator } \\
\text { 'Hey there! Lover, stop where you are.' }\end{array}$ & \\
\hline
\end{tabular}

Table 2. The opening turns of the characters who initiate the conversation with Lysidamus.

Once again the conversational and the social order will get reversed in the final scene, where the master of the house will lose full control not only over the interaction but also over his own turn space.

(13) CLEO. Quin responde, tuo quid factum est pallio?

LYS. Bacchae hercle, uxor -

CLEO. Bacchae?

LYS. Bacchae hercle, uxor -

MYRR. Nugatur sciens, / nam castor nunc Bacchae nullae ludunt.

LYS. Oblitus fui, / sed tamen Bacchae -

CLEO. Quid, Bacchae?

LYS. Sin id fieri non potest... /

CLEO. Times ecastor. (Plaut., Cas. 979-982)

['CLEO. Answer to me, what's happened to your cloak? LYS. Bacchants, my wife CLEO. Bacchants? LYS. Bacchants, my wife - MYR. He's deliberately talking nonsense: / no Bacchants are revelling now. LYS. I'd forgotten, but still, Bacchants - CLEO. What, Bacchants? LYS. If that's impossible... CLEO. You really are afraid.']

Significantly, the old man starts talking (13) after the turn is allocated to him by his wife (responde). Later on, however, due to his nonsensical and hesitating interventions, Lysidamus is interrupted four times: twice by Cleostrata, once by Myrrhina and, arguably, once by himself in a desperate, yet fruitless, search for an excuse (the suspended turn: sin id fieri non potest...). This series of turn-space encroachment acquires particular significance if one attends the fact that most of the interruptions in the Roman comedy corpus belongs to old men, who interrupt freely every other character (approx. once every 64 turns), except their male peers (Berger: forthcoming). ${ }^{30}$ Almost the only con-

30 In Plautus, the old men interrupt each other very rarely and only within representations of conflictual talk (e.g. Plaut., Cas. 605-607). See also the senex Periplectomenus when he teaches a young male elite member about the rules of orderly turn taking at a banquet (Mil. 643-648). 
text for upper-class women in Plautus to violate the turn-space of free-born characters (approx. once every 34 turns) is a dowered wife who interrupts her husband, just like Cleostrata in (13). Myrrhina, depicted as bona matrona and yet following the lead of her female friend, would be the exception that proves this rule. ${ }^{31}$

\section{Conclusions}

In the present paper, I have aimed at combining the study of im/politeness and the orderliness of talk-in-interaction in Plautus' Casina in order to trace the speech patterns of exerting power. Within the conversational styles of the comedy characters, I have identified the active interaction- and turn-managing style of domination, contrasted with the passive and responsive role of the subordinates, who often are denied the speakership or full participation in the conversation. Accordingly, the power-related phenomena concern controlling the access to the interaction - through dialogue opening - as well as interrupting and silencing the current speaker.

Furthermore, this short analysis included the cases of transgressions of political behaviour, which created interpersonal tensions (e.g. impolite evaluations) in contacts among the pater familias and other members of his household. These challenges to the male authority are key for understating Plautus' comical representation of the rebellious slave, the dowered wife, and the powerless senex amator. I have highlighted the instances in Casina where the subordinates are attempting at controlling the turn-taking system and, by extension, the interaction. Accordingly, the rebellion of Lysidamus' household has been conducted with the power-related conversational devices identified throughout the comedy corpus as part of the male language of domination. During the climax scene of the play, the master of the house was summoned and pursued by his own servant, the women have surrounded him, (improperly) greeted, and kept interrupting, while his formerly most trusted slave would not obey him and be silenced. Thus, in a single interaction, the degradation of the male conversational potestas reaches its extreme.

\section{Bibliography}

Anderson, W. S. (1983). Chalinus armiger in Plautus' Casina. Illinois Classical Studies, 8(1), 11-21.

Barbiero, E. A. (2020). What's New? The Possibilities of Novelty in Plautus' Casina. In S. Papaioannou, \& Ch. Demetriou (Eds.), Plautus' Erudite Comedy: New Insights into the Work of a doctus poeta (pp. 51-72). Cambridge: Cambridge Scholars Publishing.

Barrios-Lech, P. (2016). Linguistic Interaction in Roman Comedy. Cambridge: Cambridge University Press.

Berger, Ł. (2016). Introducing the first topic slot in Plautine dialogues. Roczniki Humanistyczne, 64(3), 89-110.

31 See Feltovich (2015: p. 250) on psychological consistency and complexity of the relation between Myrrhina and Cleostrata, who eventually "collude [...] to humiliate the master of the house". 
Berger, Ł. (2017). The Old Man and Linguistic Politeness in the Comedies of Plautus. Symbolae Philologorum Posnaniensium Graecae et Latinae, 27(3), 249-273.

Berger, Ł. (2018). Negotiating the interactional meaning on the Roman stage: tokens of phaticity. In A. Gałkowski, \& M. Kopytowska (Eds.), Current Perspectives in Semiotics. Text, Genres, and Representations (pp. 217-237). Berlin: Peter Lang.

Berger, Ł. (2019). Gestión de los turnos conversacionales en Plauto y Terencio: entre el habla y los silencios. In R. López Gregoris (Ed.), Drama y dramaturgia en Roma (pp. 281-309). Zaragoza: Pórtico.

Berger, Ł. (2020). Greeting in Roman Comedy: Register and (Im)politeness. Journal of Latin Linguistics, 19 (in press).

Berger, Ł. (forthcoming). (Im)politeness of Interruptions in Roman Comedy.

Brown, P., \& Levinson, S. C. (1987). Politeness. Some Universals in Language Usage. Cambridge: Cambridge University Press.

Cabrillana, C. (2019). Expresiones directivas con verbos de uso copulativo en la comedia latina. Glotta, 95, 8-25.

Casinos Mora, F. J. (1999). El dualismo autoridad-potestad como fundamento de la organización y del pensamiento políticos de Roma. Polis, 11, 85-109.

Cody, J. M. (1976). The 'Senex Amator' in Plautus' Casina. Hermes, 104(4), 453-476.

Culpeper, J. (2011). Politeness and impoliteness. In K. Aijmer, \& G. Andersen (Eds.), Pragmatics of society (Handbooks of Pragmatics, 5; pp. 391-436). Berlin: Mouton de Gruyter,

De Melo, W. (2011-2013). (Ed.). Plautus. Comedies (Vol. 1-5). Cambridge (MA): Cambridge University Press.

Dickey, E. (2016). Politeness in ancient Rome: Can it help us evaluate modern politeness theories? Journal of Politeness Research, 12(2). 197-220.

Feltovich, A. (2015). In Defense of Myrrhina: Friendship between Women in Plautus's Casina. Helios, 42(2), 245-266.

Geyer, N. (2008). Discourse and Politeness: Ambivalent Face in Japanese. New York: Continuum.

Goffman, E. (1955). On face-work: An analysis of ritual elements in social interaction. Psychiatry, 18(3), 213-231.

Goffman, E. (1971). Relations in Public. Macrostudies of the Public Order. New York: Basic Books.

Gotter, U. (2008). Cultural differences and cross-cultural contact: Greek and Roman concepts of power. Harvard Studies in Classical Philology, 104, 179-230.

Hall, J. (2005). Politeness and Formality in Cicero's Letter to Matius (Fam. 11.27). Museum Helveticum, 62, 193-213.

Hall, J. (2009). Politeness and Politics in Cicero's Letters. Oxford: Oxford University Press.

Haugh, M. (2007). The discursive challenge to politeness research: An interactional alternative. Journal of Politeness Research, 3(2), 295-317.

Herman, V. (1995). Dramatic discourse: Dialogue as interaction in plays. London: Routledge.

Herman, V. (2002). Turn Management in Drama. In J. Culpeper, M. Short, \& P. Verdonk (Eds.), Exploring the Language of Drama: from Text to Context (pp. 29-43). London - New York: Routledge.

Kaster, R. (2005). Emotion, Restraint, and Community in Ancient Rome. Oxford: Oxford University Press. 
Konstan, D. (2014). Turns and Returns in Plautus's Casina. In I. N. Perysinakis, \& E. Karakasis (Eds.), Plautine trends: Studies in Plautine comedy and its reception (pp. 3-11). Berlin - Boston: De Gruyter.

Laver, J. (1975). Communicative function of phatic communion. In A. Kendon, R. M. Harris, \& M. R. Key (Eds.), Organization of Behavior in Face-to-Face Interaction (pp. 215-238). The Hague: Mouton.

Levinson, S. C. (1983). Pragmatics. Cambridge: Cambridge University Press.

Levinson, S. C. (2013). Action formation and ascription. In J. Sidnell, \& T. Stivers (Eds.), The Handbook of Conversation Analysis (pp. 103-130). Malden - Oxford: Wiley-Blackwell.

MacCary, W. T., \& Willcock, M. M. (1976). (Eds.). Plautus: Casina. Cambridge: Cambridge University Press.

McCarthy, K. (2000). Slaves, Masters, and the Art of Authority in Plautine Comedy. Princeton: Princeton University Press.

Mills, S. (2003). Gender and politeness. Cambridge: Cambridge University Press.

Mills, S. (2011). Discursive approaches to politeness and impoliteness. In Linguistic Politeness Research Group (Eds.), Discursive approaches to Politeness (pp. 19-56). Berlin: De Gruyter Mouton.

Moore, T. J. (1998). The Theater of Plautus: Playing to the Audience. Austin: University of Texas Press.

Müller, R. (1997). Sprechen und Sprache. Dialoglinguistische Studien zu Terenz. Heidelberg: Universitätsverlag Winter.

O’Bryhim, S. (1989). The Originality of Plautus' Casina. The American Journal of Philology, 110(1), 81-103.

O'Connell, D. C., Kowal, S., \& Kaltenbacher, E. (1990). Turn-taking: A critical analysis of the research tradition. Journal of Psycholinguistic Research, 19(6), 345-373.

Piirainen-Marsh, A. (2005). Managing adversarial questioning in broadcast interviews. Journal of Politeness Research, 1(2), 193-217.

Rei, A. (2005). Villains, wives, and slaves in the comedies of Plautus. In S. R. Joshel, \& S. Murnaghan (Eds.), Women and slaves in Greco-Roman culture: differential equations (pp. 104-120). New York: Routledge.

Ridealgh, K., \& Unceta Gómez, L. (forthcoming). Potestas and the language of power: Conceptualising an approach to Power and Discernment politeness in ancient languages. Journal of Pragmatics.

Risselada, R. (1994). Modo and sane, or what to do with particles in Latin directives. In J. Herman (Ed.), Linguistic Studies on Latin: Selected papers from the 6th International Colloquium on Latin Linguistics (Budapest, 23-27 March 1991) (pp. 319-343). Amsterdam - Philadelphia: John Benjamins Publishing.

Sacks, H., Schegloff, E. A., \& Jefferson, G. (1974). A simplest systematics for the organization of turn-taking in conversation. Language, 50(4), 696-735.

Schegloff, E. A. (1986). The routine as achievement. Human studies, 9(2), 111-151.

Schegloff, E. A. (1987). Between micro and macro: Contexts and other connections. In J. C. Alexander (Ed.), The micro-macro link (pp. 207-234). Berkley - Los Angeles: Univ. of California Press.

Schegloff, E. A. (2007). Sequence Organization in Interaction. Cambridge: Cambridge University Press. 
Stewart, R. (2012). Plautus and Roman Slavery. Malden - Oxford: Wiley-Blackwell.

Unceta Gómez, L. (2018). Gli studi sulla (s)cortesia linguistica in latino. Possibilità di analisi e proposte per il futuro. Studi e Saggi Linguistici, 56(2), 9-37.

Unceta Gómez, L. (2019). Conceptualizations of linguistic politeness in Latin: the emic perspective. Journal of Historical Pragmatics, 20(2), 286-312.

Watts, R. J. (2003). Politeness. Cambridge: Cambridge University Press.

Zebrino, M. C. (2013). Taceo in Plauto: quando dire non è fare. Rationes rerum, 1, 115-147.

Łukasz Berger, PhD / Iberger@amu.edu.pl

Institute of Classical Philology

Adam Mickiewicz University in Poznań

Fredry 10, 61-701 Poznań, Poland 
